\title{
Bokrecension: Det omätbaras renässans - en uppgörelse med pedanternas världsherravälde
}

\author{
Lotta Jons \\ Centrum för universitetslärarutbildning \& Institutionen för matematikämnets och \\ naturvetenskapsämnenas didaktik, Stockholms universitet
}

Bornemark, Jonna (2018). Det omätbaras renässans - en uppgörelse med pedanternas världsherravälde. Stockholm: Volante, 304 sid.

Jonna Bornemark (f 1973) är docent i filosofi och lektor på Centrum för praktisk kunskap vid Södertörns högskola. Hon ägnar sig åt forskning inom fenomenologi, existensfilosofi, religionsfilosofi och praktisk kunskap och har intresserat sig för exempelvis mätbarhetens gränser, omdömets möjligheter, subjektivitet, bildning, relationen mellan människa och djur och kroppslighet. Några centrala filosofer hon fördjupat sig i är Nicolas Cusanus, Giordano Bruno, Edmund Husserl, Max Scheler, Edith Stein och Mechthild von Magdeburg.

Det omätbaras renässans - en uppgörelse med pedanternas världsherravälde utlovar inget mindre än möjligheten till en nyordning i vår mänskliga tillvaro och i för högre utbildning relevanta praktiker såsom mellanmänskliga professioner, vetenskap, religion och konst: en uppgörelse med pedanternas vurm för att mäta allt och ett återtagande av ett fenomenologiskt intresse för "det levda".

Boken adresserar vår tids "... övertro, till kalkylerande metoder och rationaliteter som sträcks ut till livets alla områden" ( $s$ 9). Detta menar Bornemark hänger samman med en tilltro till att det inte finns något $\mathrm{i}$ vår tillvaro som vi inte kan nå kunskap om, en tilltro som på ett avgörande sätt förfalskar vår förståelse av "det levande". Problematiken förstärks av en "pedantisk byråkrati som förlorar sig i en värld av regelbundenheter och generaliteter, och som tappar förmågan att relatera till unika och konkreta situationer och individer" (s I3). Med hjälp av tre renässansfilosofers syn på rationalitet lyfter Bornemark fram konsekvenserna av denna mätbarhetsvurm, såväl vad den förstärker som vad den får oss att gå miste om när vi bedriver och utvärderar verksamhet inom "livets område".

Valet av de tre renässansfilosoferna motiveras med att det däri finns såväl mystiskt/magiskt som vetenskapligt tankegods. Hos Nicholas Cusanus (I4OI-I464) finns förankring i den skolastiska tradition som höll det logiska tänkandet högt och samtidigt i den monastiska som snarare odlade mystiska tankar. Närmare bestämt är det Cusanus förståelse av förnuftet som bestående av ett kalkylerande ratio och ett reflekterande och omdömesgillt intellectus som används för att belysa skillnaden mellan det som är mätbart och "det levda", omätbara. Det sistnämnda, intellectus, står nämligen i relation till ett icke-vetande, med vilket menas "horisonter som sträcker sig bortom det vi känner till", vilka samtidigt erbjuder möjlighet till något nytt (s 34). Ur detta "livets och varats överflöd" hämtar intellectus fram "vadheter", ungefär "kvaliteter", som det överlämnar till ratiot, som i sin tur gör dem till mätbara begrepp. Icke-vetandet innefattar alltså

*Författarkontakt: lotta.jons@su.se

Artiklar och reflektioner är kollegialt granskade. Övriga bidragstyper granskas av redaktionen. Se www.hogreutbildning.se ISSN 2000-7558

(C)2019 Lotta Jons. This is an Open Access article distributed under the terms of the Creative Commons Attribution-NonCommercial 4.0 International License (https://creativecommons.org/licenses/by-nc/4.0/), allowing third parties to share their work (copy, distribute, transmit) and to adapt it, under the condition that the authors are given credit, that the work is not used for commercial purposes, and that in the event of reuse or distribution, the terms of this license are made clear.

Citation: Lotta Jons (2019) «Bokrecension: Det omätbaras renässans - en uppgörelse med pedanternas världsherravälde», Högre utbildning, 9(1), 1-5. http://dx.doi.org/10.23865/hu.v9.1553 


\section{Lotta Jons}

mer ursprungliga, icke-begreppsformade kvaliteter, som dessutom ligger närmare "det levda", framförallt genom att det innehåller det största, alltet, som knyter an till livets stora frågor och även det minsta, minimat, som återfinns i det situationsbundna och unika.

Ur Giordano Brunos (I548-1600) filosofi lånar Bornemark ett magiskt tankegods som ”... presenterar världen som levande snarare än mekanisk, men som inte desto mindre är nära förbunden med den gryende vetenskapen” (s II). Brunos tänkande passar därmed, menar författaren, speciellt bra i syfte att erbjuda det hon menar är bortträngda perspektiv i vår samtids vetenskapliga "förståelse för kalkylerbarhet, liv och materia" (s II). Från Bruno hämtar Bornemark konceptet "pedant", som "... är den som förlorar sig i regler, abstraktioner och generaliseringar och därmed tappar kontakten med de specifika situationernas konkretion" (s II). Tillsammans med ovannämnda tankar och begrepp från Cusanus och Bruno används konceptet "pedant" som resurs för att skriva fram konsekvenser såsom "förpappring", "dubbla verkligheter", "begreppsimperialism", "färrstyrning" och "livsdränering" (se nedan).

Den tredje filosof som får bidra till analysen av vår samtids mätbarhetsvurm och dess konsekvenser är René Descartes (I596-I650). Dels används Descartes inte så kända etik för att "förstå den utmattning som samtidens arbetsliv ... präglas av" (s I5). Dels utpekas hans dualism mellan kropp (res extensa) och själ (cogitans) som utgångspunkt för den cartesianska traditionens förhärskande tilltro till evidens som tillsammans med naturvetenskapliga, scientistiska och reduktionistiska förklaringsmodeller koloniserar även "livets" alla områden, och som därmed lämnar oss med ett "förklaringsgap" (se nedan).

I boken första del, Pedanternas styrsystem, undersöker Bornemark "vilka filosofiska idéer om förnuft och mätbarhet som ligger bakom den samtida utvecklingen ..., vad det är som gör att så många har en känsla av att något är allvarligt fel i det NPM ${ }^{1}$ - drivna arbetslivet ... och varför detta fel förstärks i de mellanmänskliga yrkena inom välfärden?” (s 33). Häri belyses konsekvenser av manualstyrning, kvantifiering av kvalitet och vurm för mätningar, utvärderingar och granskningar. Bornemark lånar det av Johan Hofvendal (2006) myntade begreppet "förpappring" för att klargöra den konsekvens som består i att allt som görs måste dokumenteras. När dokumentationen blir viktigare än görandet uppstår en "förpapprad parallell verklighet" (s 56) där vi också "I pedantens anda arbetar ... för att öka det område vi kan kontrollera... (genom att) ... föra över den komplexa, rörliga, självformande erfarenhetsvärlden till ett excelark..." (s 60).

En annan konsekvens är begreppsimperialism, med vilket menas att begrepp och tankesätt från andra områden - som exempelvis kostnader, effektivitet, konkurrens - koloniserar välfärdsverksamheten och tränger undan det kunnande som faktiskt finns i välfärdsprofessionerna, såsom exempelvis lyhördhet, lärande och empati. Intellectus begrepp reduceras med andra ord till ratiots begrepp vilket i sin tur, konstateras det, utarmar praktikerna ifråga. Den tredje konsekvensen som tas upp är ffärrstyrning, dvs att såväl utförare som nyttjare detaljstyrs av utifrån kommande manualer byggda på papperslogik snarare än den levda verklighetens logik, mätbarhetslogik snarare än värdelogik och utvärdering och kontroll snarare än utveckling och professionalisering.

Tillsammans bidrar dessa konsekvenser enligt författaren till den utmattning som individer inom välfärdsyrken är speciellt drabbade av i dag. Vilka möjliga alternativ till dessa konsekvenser erbjuder då Cusanus och Brunos tankegods? Här skriver Bornemark fram en intellectuspraktik där en reflekterande och omdömesgill subjektivitet förhåller sig till mätningslogiken på ett

1 New Public Management, "samlingsbegrepp för organisatoriska och styrningsrelaterade reformer inom den offentliga sektorn, ofta inspirerade av det privata näringslivet" enligt NE 2019. 
sätt som förmår ta tillvara professionens kunnande. Hon skriver att "Det centrala är att utveckla en sensibilitet för kvalitet, det vill säga för vad som är viktigt i situationen. Ett gott omdöme är därmed en sorts intellectus-förmåga som har närhet till ett icke-vetande och en egen relation till situationens minima, dess unicitet" (s 72 ).

I del två, En scientistisk livsdränering, "... undersöks vad som händer med vår förståelse av kunskap och liv i senmodernitetens ratiosamhälle" (s I5). Med utgångspunkt i Brunos åtskillnad mellan inifrånverkande princip och yttre orsak visas här hur en förstärkning av det mekanistiska i Descartes tänkande lett till ett utarmat kunskapsbegrepp som blir beroende av evidens och där enkom objektivt nådd kunskap som är möjlig att generalisera räknas. Vetenskapen dräneras på "det levande" genom att subjektivt erhållen kunskap om det situationsbundna och unika inte räknas som legitim. Häri belyses de konsekvenser som detta livsdränerade kunskapsparadigm fått för psykiatrins val av behandlingsmetoder och här utfärdas en varning för det som Bornemark karaktäriserar som ett av ratioparadigmets - och därmed pedanteriets - extrempositioner, nämligen scientismen. Richard Dawkins reduktionistiska och mekanistiska förståelse av livsbegreppet kontrasteras mot Brunos tankar om en i materian självformande princip och Cusanus förståelse av förnuftet som icke-dualistiskt för att förklara fenomenet livsdränering; den cartesianska separerande rörelse där själen och subjektiv kunskap avskiljs från en vetenskapspraktik begränsar sitt intresse till orsak-verkan-förklaringar och dränerar därmed vår vetenskapliga kunskap på "liv". Därmed uppstår också ett förklaringsgap: vi kan inte förklara varför clowners besök hos hospicepatienter minskar behovet av postoperativ smärtlindring (se Hansen 20I8).

Bornemark skriver fram en alternativ kunskapspraktik med hjälp av Brunos sammanförande av kropp och själ, form och materia och som lydande under en inifrånverkande princip som ger kroppen själ och materian form. Detta förstärks genom att koppla resonemanget till den fenomenologiska tanken om kroppen som erfarande. Till detta läggs Cusanus tanke om att motsatser sammanfaller och som säger att all kunskap härstammar från intellectus framhämtande ur icke-vetandet av de "vadheter" som det bedömer som viktigast i en situation. I ett sådant vetenskapsparadigm kan "det levande", det subjektiva och det situationsbundna och unika bevaras, användas för att förklara fenomen och få status som sanning.

Bokens tredje del, Intellectus spelplaner, belyser de missförstånd och hot om undanträngning som humaniora, religion och konst såsom intellectuspraktiker står inför i en tid styrd av ratiologik. Enligt författaren återfinns dock motkrafter till livsdräneringen inom dessa tre områden. De karaktäriseras av att intellectus tillsammans med liv, subjektivitet, erfarande och medvetande står i deras centrum. Här tillförs Cusanus sanningsbegrepp, där sanning är en av intellectus skapad mångfaldig sanningserfarenhet i samband med utvinnandet av vadheter ur icke-vetandet. Här återupprättas legitimiteten i humanioras sätt att skapa kunskap och dess status i en hälsosam kunskaps- och samhällsutveckling. Humanioras intellectuspraktik erbjuder nämligen I) att begrepp och tankesätt omförhandlas så att de bättre tjänar sin samtid, 2) att vi kan skapa kunnande relaterat till det situationsbundna och unika liksom till 3) det oändliga och livets existentiella frågor. De två sistnämnda, betonar författaren, är å ena sidan avgörande i mellanmänskliga yrken men å andra sidan "borttappad i vår kunskapstradition" (s 207). Ett fjärde område där humaniora behövs är bildningens. Den behövs som motkraft till den instrumentalisering som inom högre utbildning alltmer kommit att fokusera på att utbilda till "anställningsbarhet", dvs till samhällsnytta. Vad som behövs är snarare bildade medborgare som kan reflektera över värderingar och etablerade praktiker. Utan intellectus och bildning, avslutar författaren kapitlet om humaniora, riskerar vi att inte kunna hantera de miljö- och folkhälsoproblem som världen står inför i dag. 


\section{Lotta Jons}

På religionens område visar Bornemark hur religiösa begrepp glidit och bytt betydelser och på så vis resulterat i att skillnaden mellan fundamentalistiska ratiopraktiker å ena sidan och sökande intellectuspraktiker å den andra snarare återfinns mellan olika religioner och vetenskaper än mellan religion och vetenskap. Det som är intressant för vår samtid, menar hon, är när religiösa tanketraditioner återupptas i syfte att kunna "stå i relation till ett icke-vetande" snarare än för att de erbjuder möjlighet till konfession och färdiga svar. Det tredje området, konsten, beskrivs som en intellectuspraktik i kontakt med tillvarons magi. Magi karaktäriseras här med Bruno som människans förmåga att följa med och förstärka tillvarons skapande rörelse, dvs en kreativ förmåga som i konst kommer till uttryck som uppfångande av vadheter. Det konstnärliga skapandet innebär att ratiots begrepp förs till icke-vetandets gräns, undersöks avseende relationen till sina egna vadheter och antingen omformas, fördjupas eller förkastas. "Detta", konstaterar Bornemark, "är konstens kritiska potential, att undersöka sin samtids centrala system och begrepp ..." (s 250). Mot bakgrund av sanningserfarenhetens mångfaldiga karaktär är det just genom att ta del av denna konst som vi människor kan utvidga vår förståelse för tillvaron och det samhälle vi lever i.

Det omätbaras renässans kunde antagligen inte vara mer aktuell och behövd. Genom att använda utvalda koncept från framförallt Cusanus och Bruno sätter Bornemark ord och tankar på samtidens stelnade ratiopraktiker inom arbetslivet, vetenskapen och konsten. Hon tillämpar därmed den intellectuspraktik som hon själv efterlyser i boken och som exempelvis Gilles Deleuze och Félix Guattari (1994) beskrivit som en fråga om att applicera gamla begrepp på nya praktiker i syfte att identifiera anomalier och tänka nytt. Vad som åstadkoms kan beskrivas som det som Richard Rorty (2004) talat om som efterlängtade ombeskrivningar som har potential att nå publik framgång därför att de tillfredsställer en kollektiv efterfrågan i samtiden: de erbjuder förnyande verktyg att tänka och tala om tillvaron och att konstituera sin mänsklighet och sin praktik på ett nytt sätt. Ett "bevis" på detta är att ordet "förpappring" lades till 2018 års nya svenska ord (se Institutet för språk och folkminnen 20I8).

Bokens resonemang vittnar om ett omfattande och samtidigt imponerande djupgående filosofiskt och praktiskt kunnande som författaren skickligt omsätter i kvalificerade resonemang, och med ett språk som framställer de avhandlade temana i ett för läsaren förklarat ljus. Uppgörelsen med pedanternas världsherravälde tar sig uttryck i ett språk karaktäriserat av fenomenologiska, många gånger nyskapa(n)de termer, och på så sätt lämnar Bornemark läsaren med en vokabulär som ger henne möjlighet att verkställa uppgörelsen i sin egen praktik.

Vad saknas då i boken? Bornemark är forskare i filosofi och verksam inom den praktiska kunskapens fält, vilket torde ha anknytning till den filosofiska pedagogiken. I boken återfinns tankegods och resonemang som "resonerar" med forskning inom pedagogisk filosofi, men där finns inga sådana referenser. Man undrar till exempel hur bokens resonemang förhåller sig till Gert Biestas Good education in an age of measurement (2010). Bokens resonemang rör sig också flera gånger i närheten av relationella tankegångar, och även på detta område hade det varit intressant att få en vink om hur Bornemarks utsnitt ur den filosofiska traditionen förhåller sig till pedagogikens teoretiska och filosofiska relationism (se t.ex. Jons 2008).

\section{REFERENSER}

Biesta, Gert (2010). Good education in an age of measurement: ethics, politics, democracy. In: Interventions: education, philosophy \& culture. Boulder, Colorado: Paradigm Publishers.

Bornemark, Jonna (2018). Det omätbaras renässans - en uppgörelse med pedanternas världsherravälde. Stockholm: Volante. 
Deleuze, Gilles \& Guattari, Félix (1994). What is Philosophy? (Translated by Hugh Tomlinson \& Graham Burchill). London: Verso.

Hansen, Paul (2018). Att skratta högt där döden ser. Dagens nyheters Stockholmsbilaga, 29 december, s. 4-6. Hofvendahl, Johan (2006). Noa har inga fel: om bristfokus i skolans utvecklingssamtal. Utbildning \& Demokrati, 15(3), 61-81.

Institutet för språk och folkminnen. Nyordslistan 2018, http://www.sprakochfolkminnen.se/sprak/nyord/ nyordslistan-2018.html, hämtad 2018-12-29

Jons, Lotta (2008). Till-tal och an-svar. En konstruktion av pedagogisk hålning. Doktorsavhandling vid Pedagogiska institutionen, nr 147. Stockholm; Stockholms universitet.

Nationalencyklopedin, https://www.ne.se/uppslagsverk/encyklopedi/l\%C3\%A5ng/new-public-management, hämtad 2019-01-07

Rorty, Richard (2004). Universalitet och sanning. (Översättning Sven-Erik Torhell). I: Skirbekk, Gunnar (red). Striden om sanningen. Göteborg: Daidalos. 